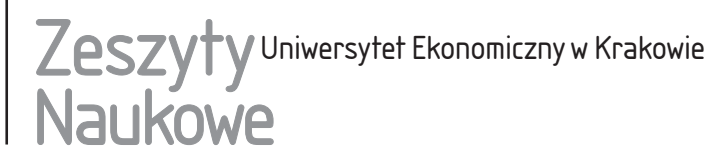

\title{
Upadłość przedsiębiorstw w Polsce na tle krajów Unii Europejskiej w latach 2005-2014
}

\section{Streszczenie}

Upadłość przedsiębiorstw jest nieodzownym elementem każdej gospodarki rynkowej i dotyczyć może każdego przedsiębiorstwa. Powszechność zjawiska skłania do analizy liczby upadłości w Polsce w porównaniu z innymi państwami członkowskimi Unii Europejskiej w latach 2005-2014. Przedmiotem badania jest ocena procesu upadłościowego państw na podstawie takich wskaźników, jak: czas likwidacji firmy, koszt oraz stopa zwrotu. Hipoteza badawcza zakłada, że przebieg procesu upadłościowego zależy od jakości prawa upadłościowego poszczególnych państw członkowskich. Analiza danych pozwoliła stwierdzić, że w Polsce przebieg procesu upadłościowego jest długi i kosztowny przy jednoczesnej niskiej stopie zwrotu. Nieefektywny system upadłościowy Polski zniechęca przedsiębiorców do wyboru formalnej ścieżki opuszczenia rynku i plasuje Polskę daleko w rankingu europejskich systemów upadłościowych.

Słowa kluczowe: upadłość przedsiębiorstw, likwidacja, prawo upadłościowe, system upadłościowy.

\section{Wprowadzenie}

Zjawisko upadłości jest nieodzownym elementem każdej gospodarki rynkowej i dotyczyć może każdego przedsiębiorstwa. Chociaż obowiązujący system polityczny, gospodarczy i prawny danego kraju wpływa na poziom oraz strukturę upadłości, to jest ona powszechna i stale towarzyszy gospodarkom narodowym. Postępujące procesy globalizacji oraz internacjonalizacji działalności spowodo- 
wały większe zależności i powiązania pomiędzy przedsiębiorstwami, co często powoduje zaistnienie upadłości w krajach powiązanych gospodarczo. Bankructwo lub nawet przejściowe kłopoty z płynnością finansową jednego przedsiębiorstwa pociągają za sobą negatywne konsekwencje dla innych. Choć upadłość, ze względu na ryzyko niewypłacalności, kojarzona jest głównie z niepowodzeniem działalności gospodarczej, nie musi oznaczać porażki. Najnowsze badania nad przedsiębiorczością wykazały, że bardziej efektywne i skuteczne w swej działalności są przedsiębiorstwa, których zarząd bądź kierownictwo nie poradziło sobie w zarządzaniu i prowadzeniu poprzedniego przedsięwzięcia. Firmy te rozwijają się szybciej i uzyskują pozytywne wyniki [Doing Business... 2015]. Upadłość zatem należy traktować jako naturalny czynnik eliminujący najsłabsze, nieefektywne lub źle zarządzane podmioty w gospodarce rynkowej.

Powszechność oraz złożoność zjawiska skłaniają do podjęcia próby zidentyfikowania skali procesu upadłościowego w Polsce na tle krajów Unii Europejskiej po 2004 r. Badania opierają się na danych uzyskanych z raportów wywiadowni Creditreform o nazwie Insolvenzen in Europa za lata 2005-2015, takich jak liczba upadłości w poszczególnych krajach europejskich w badanym okresie. Ze względu na różne daty akcesji do UE krajów członkowskich brakuje danych sprzed 2008 r. dotyczących Bułgarii, Chorwacji czy Rumunii Wyłączonymi z badania są również Malta i Cypr.

Drugim, istotnym obszarem badań jest charakterystyka procesu upadłościowego Polski na tle krajów Unii Europejskiej na podstawie wskaźników zjawiska w raportach Doing Business, a mianowicie: czasu upadłości, kosztu upadłości oraz stopy zwrotu. Wskaźniki te obejmują wszystkie kraje unijne w okresie 2005-2014. Dodatkowo zwrócono uwagę na nowy wskaźnik siły upadłości przedsiębiorstw (strength of insolvency framework index [Doing Business... 2015]), który jest syntezą oceny polityki upadłościowej poszczególnych państw członkowskich oraz implementacji unijnego prawa upadłościowego w krajach tego ugrupowania.

Celem badawczym artykułu jest próba sklasyfikowania Polski na tle krajów członkowskich Unii Europejskiej pod względem liczby upadłości przedsiębiorstw w latach 2005-2014 oraz pod względem oceny procesu upadłościowego. Hipoteza badawcza zakłada, że przebieg procesu upadłościowego przedsiębiorstwa zależy w dużej mierze od jakości prawa upadłościowego poszczególnych państw członkowskich i jest weryfikowana za pomocą wskaźników (czasu, kosztu oraz stopy zwrotu). 


\section{Upadłość przedsiębiorstw w Unii Europejskiej w ujęciu teoretycznym}

Pojęcie upadłości, stosowane zamiennie z niewypłacalnością czy z bankructwem, nastręcza wiele problemów definicyjnych. Zgodnie z definicjami upadłości w literaturze przedmiotu, ich różnymi aspektami i podejściem prezentowanym przez różnych autorów, upadłość należy rozpatrywać w dwóch wariantach: po pierwsze jako upadłość ekonomiczną przedsiębiorstwa, która wiąże się z jego kondycją finansową i oznacza wystąpienie takiego stanu w przedsiębiorstwie, który uniemożliwia prowadzenie działalności bez pomocy zewnętrznej (np. umorzenia części długów, dokapitalizowania przedsięwzięcia, połączenia dwóch podmiotów itp.); po drugie jako upadłość sądową, przez którą rozumie się zbiór zasad i procedur regulowanych prawem upadłościowym, podjętych w drodze prawnej w stosunku do podmiotu, który nie jest w stanie samodzielnie konkurować na rynku [Prusak 2011].

W literaturze podaje się różne rodzaje upadłości. Jeżeli za kryterium uzna się podmiot, co do którego ogłaszana jest upadłość, to wyróżnia się upadłość biznesową (przedsiębiorcy) i niebiznesową (konsumencką). Jeżeli za kryterium uzna się zasięg obowiązywania postępowania upadłościowego, wyróżnić będzie można: upadłość transgraniczną (występowanie majątku i/lub zobowiązań dłużnika w co najmniej dwóch państwach) i upadłość terytorialną (majątek zlokalizowany na terytorium jednego kraju). Upadłość przedsiębiorstwa może wywoływać wiele skutków w sferze społecznej, powodować kryzys ekonomiczny regionu, kraju, wtedy oznacza to upadłość systemową, a jeżeli takie okoliczności nie zaistnieją, upadłość nazywa się odizolowaną [Prusak 2011].

Pierwsze próby stworzenia prawa regulującego kwestie upadłości dla państw zjednoczonych we Wspólnocie Europejskiej miały miejsce już w 1960 r. Wtedy to podjęto prace, których efektem były dwa projekty ogłoszone w latach 1970 i 1980, dotyczące możliwości wszczęcia w państwach członkowskich tylko jednego postępowania dotyczącego niewypłacalności, a które miało być uznawane i respektowane przez pozostałych członków. Krytyka poszczególnych postulatów przez państwa członkowskie spowodowała odrzucenie projektów i stała się przyczynkiem do opracowania w 1984 r. przez Radę Europy tzw. konwencji stambulskiej. Jej głównym celem była regulacja kompetencji zarządcy zagranicznego w innych państwach członkowskich, zgłaszania wierzytelności wierzycieli zagranicznych i koordynowanie wtórnego postępowania w sprawie niewypłacalności w państwach Wspólnoty. Pomimo podpisania konwencji przez członków Rady Europy nie została ona ratyfikowana, a jako powód podano zbyt wąski zakres regulacji prawnych. Kolejnym projektem była konwencja w sprawach niewypłacalności opracowana przez ministrów sprawiedliwości państw 
członkowskich w 1995 r. Pomimo rozszerzenia zakresu regulacji prawnych również nie weszła w życie ze względu na brak podpisu aktu ze strony Wielkiej Brytanii. W 1999 r. Komisja Europejska, z inicjatywy Niemiec i Finlandii, przedstawiła Radzie Unii Europejskiej nowy projekt dotyczący postępowania upadłościowego tym razem $\mathrm{w}$ formie rozporządzenia. W brzmieniu był on bardzo zbliżony do konwencji z 1995 r. Po pozytywnej opinii parlamentu Europejskiego i Komitetu Społeczno-Ekonomicznego 29 maja 2000 r. weszło w życie Rozporządzenie nr 1346/2000 w sprawie postępowania upadłościowego [Armatowska 2011].

W systemie prawa upadłościowego Unii Europejskiej głównym aktem jest Rozporządzenie Rady (WE) nr 1346/2000 z dnia 29 maja 2000 r. w sprawie postępowania upadłościowego (Dz.Urz. WE L 160 z 30.06.2000) nieodnoszącego się jednak do postępowań upadłościowych zakładów ubezpieczeń, instytucji kredytowych, przedsiębiorstw inwestycyjnych świadczących usługi obejmujące przechowywanie środków pieniężnych oraz papierów wartościowych osób trzecich, a także przedsiębiorstw zbiorowego inwestowania. Regulacje procesów upadłościowych wspomnianych podmiotów znajdują się w odrębnych rozporządzeniach. Charakter prawny rozporządzenia unijnego pozwala na bezpośrednie obowiązywanie w systemie prawnym kraju członkowskiego i nie wymaga transformacji do prawa krajowego. Pozwala to na powoływanie się na przepisy prawa unijnego przed sądami krajowymi w celu dochodzenia swoich praw [Zedler, Hrycaj i Filipiak 2011].

\section{Analiza skali upadłości w Unii Europejskiej}

Skala zjawiska upadłości przedsiębiorstw w krajach UE ma odzwierciedlenie w danych publikowanych corocznie w raportach Insolvenzen in Europa. W pierwszym roku badanego okresu, tj. w 2005 r., liczba ich wynosiła około 165 tys., a 10 lat później wzrosła o ponad 60\% (2014 r. - 268 tys. upadłości). W głównej mierze na ten fakt wpłynął przede wszystkim ogólnoświatowy kryzys finansowy i gospodarczy, ale także dołączenie trzech nowych państw członkowskich w badanym okresie [Insolvenzen in Europa 2006, 2010, 2015].

Tabela 1. Liczba upadłości w krajach Unii Europejskiej w latach 2005-2014

\begin{tabular}{|c|c|c|c|c|c|c|c|c|c|c|}
\hline Kraj & 2005 & 2006 & 2007 & 2008 & 2009 & 2010 & 2011 & 2012 & 2013 & 2014 \\
\hline Austria & 7136 & 6854 & 6362 & 6500 & 7050 & 6657 & 6194 & 6266 & 5626 & 5600 \\
\hline Belgia & 7878 & 7617 & 7678 & 8476 & 9430 & 9570 & 10224 & 10587 & 11739 & 10736 \\
\hline Bułgaria & - & - & - & - & - & 700 & 685 & 383 & 1232 & 1031 \\
\hline $\begin{array}{l}\text { Chorwa- } \\
\text { cja }^{\text {a }}\end{array}$ & - & - & - & 875 & 940 & 1501 & 4878 & 6922 & 9019 & 7776 \\
\hline
\end{tabular}


cd. tabeli 1

\begin{tabular}{|l|r|r|r|r|r|r|r|r|r|r|}
\hline \multicolumn{1}{|c|}{ Kraj } & 2005 & 2006 & 2007 & 2008 & 2009 & 2010 & 2011 & 2012 & 2013 & 2014 \\
\hline Czechyb $^{\mathrm{b}}$ & 3882 & 4227 & 4250 & 4600 & 8394 & 5559 & 6753 & 8398 & 6021 & 3563 \\
\hline Dania & 2497 & 1987 & 2401 & 3709 & 5600 & 6461 & 5468 & 5456 & 4993 & 4049 \\
\hline Estonia & 265 & 228 & 234 & 428 & 631 & 504 & 623 & 506 & 469 & 428 \\
\hline Finlandia & 2278 & 2285 & 2254 & 2612 & 3310 & 2864 & 2944 & 2956 & 3131 & 2954 \\
\hline Francja & 41930 & 40360 & 42532 & 49723 & 55800 & 51060 & 49506 & 59556 & 60980 & 60548 \\
\hline Grecja & 612 & 532 & 524 & 359 & 360 & 355 & 445 & 415 & 392 & 330 \\
\hline Hiszpania & 869 & 853 & 880 & 2528 & 4900 & 4845 & 5910 & 7799 & 8934 & 6392 \\
\hline Holandia & 6780 & 5941 & 7952 & 6847 & 10500 & 7211 & 6176 & 7373 & 8375 & 6645 \\
\hline Irlandia & 327 & 304 & 363 & 773 & 1400 & 1525 & 1638 & 1684 & 1365 & 1164 \\
\hline Litwa & 773 & 808 & 814 & 731 & 1168 & 1496 & 1302 & 1354 & 1561 & 1593 \\
\hline Luksem- & 682 & 634 & 680 & 590 & 698 & 918 & 961 & 1033 & 1016 & 845 \\
burg & & & & & & & & & & \\
\hline Łotwa & 830 & 1174 & 1272 & 1296 & 2192 & 2407 & 813 & 881 & 818 & 950 \\
\hline Niemcy & 36850 & 34040 & 29150 & 29580 & 34300 & 32060 & 30120 & 28720 & 26120 & 24030 \\
\hline Polska & 793 & 576 & 447 & 425 & 590 & 665 & 762 & 908 & 926 & 864 \\
\hline Portugalia & 2300 & 2400 & 2123 & 3267 & 4450 & 5144 & 6077 & 7763 & 8131 & 7200 \\
\hline Rumunia & - & - & - & 14483 & 20800 & 21692 & 22650 & 26807 & 27924 & 20696 \\
\hline Słowacja & 2200 & 2150 & 2100 & 582 & 900 & 830 & 870 & 866 & 880 & 831 \\
\hline Słowenia & 1383 & 1246 & 1240 & 657 & 749 & 510 & 675 & 595 & 941 & 1302 \\
\hline Szwecja & 5865 & 5243 & 5791 & 6298 & 7600 & 7546 & 7229 & 7737 & 7701 & 7158 \\
\hline Węgry & 7983 & 9447 & 9500 & 11322 & 14637 & 17487 & 30757 & 50224 & 46398 & 60637 \\
\hline $\begin{array}{l}\text { Wielka } \\
\text { Brytania }\end{array}$ & 13462 & 13686 & 12893 & 16268 & 20300 & 17468 & 18467 & 17765 & 16021 & 15240 \\
\hline Włochyd & 17150 & 8827 & 5518 & 6498 & 9098 & 10089 & 10844 & 12311 & 14272 & 16101 \\
\hline Razem & 164725 & 151419 & 146958 & 179427 & 225797 & 217124 & 232971 & 275265 & 274985 & 268663 \\
UE-26 & & & & & & & & & & \\
\hline
\end{tabular}

Uwaga: dla Malty i Cypru brak danych.

a zawiera niezakończone postępowania upadłościowe z lat poprzednich

b od 2013 r. upadłości podmiotów prowadzących działalność na własny rachunek zostały wliczane do upadłości prywatnych, a nie przedsiębiorstw

c zawiera bankructwa oraz inne likwidacje

d od 2006 r. statystyki upadłościowe dotyczące tylko upadłości głównej siedziby firmy, nie uwzględnia się ewentualnej upadłości oddziałów

Źródło: [Insolvenzen in Europa 2006, 2010, 2015].

Z danych zaprezentowanych w tabeli 1 wynika, że Polska w 2014 r. znajdowała się na piątym miejscu w rankingu krajów o najmniejszej liczbie upadłości. 
Znacznie więcej upadłości firm odnotowują kraje należące do tzw. starej Unii, jak i większość krajów „nowej Unii” (2014 r. - Bułgaria, Chorwacja, Czechy, Litwa, Rumunia, Słowenia, Węgry). Dalsza analiza danych pozwala zauważyć, że od 2008 r. następuje wyraźny wzrost upadłości przedsiębiorstw we wszystkich krajach Unii, co jest konsekwencją globalnego kryzysu finansowego, który rozpoczął się pod koniec 2007 r. Obliczony współczynnik korelacji ${ }^{1}$ pomiędzy liczbą upadłości w Unii Europejskiej a stopą wzrostu PKB osiągniętego przez kraje członkowskie w latach 2006-2014 wynosi -0,35. Ujemny współczynnik oznacza, że wraz ze zwiększaniem się tempa wzrostu PKB w UE spada liczba upadłości w ugrupowaniu. Jest to jednak korelacja niska, chociaż zależność wyraźna. Stan gospodarki unijnej, mierzony stopą wzrostu PKB całej Wspólnoty, wykazywał tendencję wzrostową od 2005 do 2008 r. Unijne PKB wzrosło wtedy o prawie $13 \%$ z około 11,5 do około 13 bln euro. Znaczący spadek zauważa się w 2009 r. o prawie 750 mld euro, co stanowi około $6 \%$ ówczesnego PKB. Po tym okresie odnotowuje się systematyczny, stopniowy wzrost unijnego PKB, by w 2014 r. wyniósł 13,9 bln euro. Początkowy coroczny przyrost PKB sprzyjał spadkowi liczby upadłości ogółem w UE. Znaczący przełom nastąpił po 2008 r., kiedy to w okresie kolejnych czterech lat wzrastała liczba upadłości. Zmiana trendu nastąpiła dopiero w 2013 r.

Opisana powyżej relacja pomiędzy stanem unijnej gospodarki, na którą mocno wpłynął światowy kryzys, a liczbą upadłości dotyczyła Unii Europejskiej jako jednego podmiotu. Jednak gdy analizie poddane zostaną poszczególne kraje Wspólnoty, liczba procesów upadłościowych w badanym okresie ulegała wahaniom nie tylko w momencie wybuchu kryzysu, ale na przestrzeni 10 lat. Polska jest przykładem kraju o stosunkowo niewielkim wzroście postępowań upadłościowych w 2014 r. w stosunku do 2005 r. Znaczące zmiany miały miejsce w 2009 r., kiedy została zatrzymana tendencja spadkowa liczby upadłości. Zupełnie inna sytuacja miała miejsce w przypadku Węgier, Chorwacji czy Hiszpanii, gdzie liczba upadłości systematycznie wzrastała z roku na rok, by w 2014 r. osiągnąć około 8-krotnie wyższą wartość niż w 2005 r. Znaczny wzrost odnotowały również Irlandia (4-krotny wzrost) oraz Grecja, Portugalia, Litwa i Estonia (2-krotny wzrost liczby upadłości w badanym przedziale czasowym). Ponadto Francja, Belgia, Dania, Szwecja są państwami, w których wielkość upadłości w 2014 r. zwiększyła się o około 50\% w stosunku do 2005 r. Krajami, w których liczba upadłości w badanym okresie zmniejszyła się, są: Słowacja (spadek 3-krotny), Grecja (spadek 2-krotny) oraz Niemcy (spadek o 30\%). Pozostałe kraje, takie jak: Czechy, Włochy, Austria, Holandia, odnotowały kilku- lub kilkunastoprocentowy

1 Współczynnik korelacji Pearsona $r=-0,35$ obliczony na podstawie danych Eurostat (http:// appsso.eurostat.ec.europa.eu/nui/show.do, dostęp: 14.05.2014) i Insolvenzen in Europa za lata 2006-2015. 
spadek liczby upadłości w 2014 r. w stosunku do 2005 r. Są to kraje, w których tendencje upadłościowe w badanym okresie ulegały zmianom wskutek kryzysu.

\section{Wskaźniki upadłości przedsiębiorstw - czas, koszt oraz stopa zwrotu}

Analiza upadłości przedsiębiorstw w krajach UE, wyrażonej w wielkościach bezwzględnych, nie pozwoliła na jednoznaczną ocenę procesów upadłościowych krajów członkowskich. Nie zauważono zależności pomiędzy liczbą upadłości a chociażby „stażem w Unii”. Pierwotnie wydawać by się mogło, że im późniejsza data akcesji, tym bardziej utrudnione warunki prowadzenia biznesu, zwłaszcza międzynarodowego, a tym samym większe ryzyko potencjalnego niepowodzenia czy bankructwa. Dotychczasowa analiza nie wykazała takiego związku, stąd kolejnym etapem badań stała się identyfikacja procesu upadłościowego pod kątem trzech głównych wskaźników: okresu likwidacji, kosztu likwidacji oraz stopy zwrotu [Doing Business... 2015]. Wskaźniki te pomogą lepiej zidentyfikować proces upadłości pod względem sformalizowania procesu w krajach Unii.

Czas przeprowadzenia procesu upadłościowego (w latach - T) oznacza okres, jaki upływa od złożenia wniosku o likwidację firmy do ogłoszenia wyroku w tej sprawie. Wartość ta jest pochodną procedur upadłościowych, ich liczby i złożoności w danym kraju oraz możliwości ewentualnego prowadzenia ich jednocześnie. Wskaźnik ten dodatkowo uwzględnia czas odwołań od decyzji, apelacje. Koszt upadłości (wyrażony w \% - C) rozumiany jest jako wartość procentowa majątku likwidowanej firmy. Koszt szacowany jest na bazie rzeczywistych wyników badań prowadzonych przez praktyków upadłościowych i obejmuje następujące elementy: opłaty sądowe, opłaty niezależnych ekspertów (rzeczoznawców), syndyka, prawników, adwokatów, opłaty księgowe. Stopa zwrotu (Rr) mierzy liczbę centów uzyskanych z dolara od dłużnika w drodze postępowania upadłościowego (reorganizacji lub likwidacji przedsiębiorstwa).

W celu identyfikacji wyżej wymienionych wskaźników dla państw członkowskich w dwóch tabelach podano dane za lata 2005-2014. Jako kryterium pogrupowania państw przyjęto 2004 r. W tabeli 2 zamieszczono państwa Europy Zachodniej będące członkami UE przed 2004 r., natomiast w tabeli 3 - państwa, których akcesja przypada na 2004 r. lub później.

W przypadku pierwszej grupy krajów (UE-15) zauważa się krótki czas trwania procesu upadłościowego. W badanej grupie jest on zasadniczo krótszy niż 2 lata. Wyjątkiem są Grecja i Dania, gdzie czas ten wynosi około 3 lat, przy czym w Danii wartość ta w badanym okresie malała z roku na rok (z 3,3 do 3,1 roku), natomiast w Grecji zwiększała się z 2 lat w 2005 r. do 2,9 roku w 2014 r. Najkrótszy czas 
Tabela 2. Czas (T), koszt (C) oraz stopa zwrotu (Rr) w państwach UE-15 w latach 2005-2014

\begin{tabular}{|c|c|c|c|c|c|c|c|c|c|c|c|c|c|c|c|}
\hline \multirow{2}{*}{ Rok } & \multicolumn{3}{|c|}{ Austria } & \multicolumn{3}{|c|}{ Belgia } & \multicolumn{3}{|c|}{ Dania } & \multicolumn{3}{|c|}{ Finlandia } & \multicolumn{3}{|c|}{ Francja } \\
\hline & $\mathrm{T}$ & $\mathrm{C}$ & $\mathrm{Rr}$ & $\mathrm{T}$ & $\mathrm{C}$ & $\mathrm{Rr}$ & $\mathrm{T}$ & $\mathrm{C}$ & $\mathrm{Rr}$ & $\mathrm{T}$ & $\mathrm{C}$ & $\mathrm{Rr}$ & $\mathrm{T}$ & $\mathrm{C}$ & $\mathrm{Rr}$ \\
\hline 2005 & 1,1 & 18 & 73,3 & 0,9 & 3,5 & 86,6 & 3,3 & 4 & 67,2 & 1 & 4 & 89,0 & 2 & 9 & 47,5 \\
\hline 2006 & 1,1 & 18 & 73,7 & 0,9 & 3,5 & 86,7 & 3,4 & 4 & 67,3 & 1 & 4 & 89,1 & 2 & 9 & 47,6 \\
\hline 2007 & 1,1 & 18 & 72,4 & 0,9 & 3,5 & 86,8 & 3,5 & 4 & 67,4 & 1 & 4 & 89,2 & 2 & 9 & 47,7 \\
\hline 2008 & 1,1 & 18 & 71,5 & 0,9 & 3,5 & 86,9 & 3,6 & 4 & 67,5 & 1 & 4 & 89,3 & 2 & 9 & 47,8 \\
\hline 2009 & 1,1 & 18 & 71,5 & 0,9 & 3,5 & 86,10 & 3,7 & 4 & 67,6 & 1 & 4 & 89,4 & 2 & 9 & 47,9 \\
\hline 2010 & 1,1 & 18 & 73,1 & 0,9 & 3,5 & 86,11 & 3,8 & 4 & 67,7 & 1 & 4 & 89,5 & 2 & 9 & 47,10 \\
\hline 2011 & 1,1 & 18 & 72,7 & 0,9 & 3,5 & 86,12 & 3,9 & 4 & 67,8 & 1 & 4 & 89,6 & 2 & 9 & 47,11 \\
\hline 2012 & 1,1 & 10 & 83,3 & 0,9 & 3,5 & 86,13 & 3,10 & 4 & 67,9 & 1 & 4 & 89,7 & 2 & 9 & 47,12 \\
\hline 2013 & 1,1 & 10 & 82,4 & 0,9 & 3,5 & 86,14 & 3,11 & 4 & 67,10 & 1 & 4 & 89,8 & 2 & 9 & 47,13 \\
\hline 2014 & 1,1 & 10 & 82,6 & 0,9 & 3,5 & 86,15 & 3,12 & 4 & 67,11 & 1 & 4 & 89,9 & 2 & 9 & 47,14 \\
\hline \multirow{2}{*}{ Rok } & \multicolumn{3}{|c|}{ Hiszpania } & \multicolumn{3}{|c|}{ Szwecja } & \multicolumn{3}{|c|}{ W. Brytania } & \multicolumn{3}{|c|}{ Włochy } & \multicolumn{3}{|c|}{ Luksemburg } \\
\hline & $\mathrm{T}$ & $\mathrm{C}$ & $\mathrm{Rr}$ & $\mathrm{T}$ & $\mathrm{C}$ & $\mathrm{Rr}$ & $\mathrm{T}$ & $\mathrm{C}$ & $\mathrm{Rr}$ & $\mathrm{T}$ & $\mathrm{C}$ & $\mathrm{Rr}$ & $\mathrm{T}$ & $\mathrm{C}$ & $\mathrm{Rr}$ \\
\hline 2005 & 1,5 & 14,5 & 74,1 & 2 & 9 & 74,9 & 1 & 6 & 85,3 & 2 & 22 & 63,6 & - & - & - \\
\hline 2006 & 1,5 & 14,5 & 73,8 & 2 & 9 & 75,7 & 1 & 6 & 85,2 & 2 & 22 & 63,7 & 2 & 14,5 & 41,6 \\
\hline 2007 & 1,5 & 14,5 & 72,8 & 2 & 9 & 74,7 & 1 & 6 & 84,6 & 2 & 22 & 63,8 & 2 & 14,5 & 41,6 \\
\hline 2008 & 1,5 & 14,5 & 67,6 & 2 & 9 & 75,1 & 1 & 6 & 84,2 & 2 & 22 & 63,9 & 2 & 14,5 & 41,7 \\
\hline 2009 & 1,5 & 14,5 & 67,6 & 2 & 9 & 75,1 & 1 & 6 & 84,2 & 2 & 22 & 63,10 & 2 & 14,5 & 41,7 \\
\hline 2010 & 1,5 & 11 & 70,5 & 2 & 9 & 77,3 & 1 & 6 & 88,6 & 2 & 22 & 63,11 & 2 & 14,5 & 43,7 \\
\hline 2011 & 1,5 & 11 & 75,6 & 2 & 9 & 75,8 & 1 & 6 & 88,6 & 2 & 22 & 63,12 & 2 & 14,5 & 43,5 \\
\hline 2012 & 1,5 & 11 & 76,5 & 2 & 9 & 74,7 & 1 & 6 & 88,6 & 2 & 22 & 63,13 & 2 & 14,5 & 43,5 \\
\hline 2013 & 1,5 & 11 & 72,3 & 2 & 9 & 75,5 & 1 & 6 & 88,6 & 2 & 22 & 63,14 & 2 & 14,5 & 43,5 \\
\hline 2014 & 1,5 & 11 & 71,3 & 2 & 9 & 76,1 & 1 & 6 & 88,6 & 2 & 22 & 63,15 & 2 & 14,5 & 44,0 \\
\hline \multirow{2}{*}{ Rok } & \multicolumn{3}{|c|}{ Niemcy } & \multicolumn{3}{|c|}{ Grecja } & \multicolumn{3}{|c|}{ Irlandia } & \multicolumn{3}{|c|}{ Holandia } & \multicolumn{3}{|c|}{ Portugalia } \\
\hline & $\mathrm{T}$ & $\mathrm{C}$ & $\mathrm{Rr}$ & $\mathrm{T}$ & $\mathrm{C}$ & $\mathrm{Rr}$ & $\mathrm{T}$ & $\mathrm{C}$ & $\mathrm{Rr}$ & $\mathrm{T}$ & $\mathrm{C}$ & $\mathrm{Rr}$ & $\mathrm{T}$ & $\mathrm{C}$ & $\mathrm{Rr}$ \\
\hline 2005 & 1 & 8 & 81,3 & 2,0 & 9 & 45,9 & 0,4 & 9 & 88,0 & 1,1 & 3,5 & 88,4 & 2 & 9 & 74,7 \\
\hline 2006 & 1 & 8 & 81,4 & 2,1 & 9 & 46,3 & 0,4 & 9 & 88,1 & 1,1 & 3,5 & 88,5 & 2 & 9 & 75,0 \\
\hline 2007 & 1 & 8 & 81,5 & 2,2 & 9 & 44,8 & 0,4 & 9 & 88,2 & 1,1 & 3,5 & 88,6 & 2 & 9 & 74,0 \\
\hline 2008 & 1 & 8 & 81,6 & 2,3 & 9 & 44,2 & 0,4 & 9 & 88,3 & 1,1 & 3,5 & 88,7 & 2 & 9 & 69,4 \\
\hline 2009 & 1 & 8 & 81,7 & 2,4 & 9 & 44,2 & 0,4 & 9 & 88,4 & 1,1 & 3,5 & 88,8 & 2 & 9 & 69,4 \\
\hline 2010 & 1 & 8 & 81,8 & 2,5 & 9 & 43,2 & 0,4 & 9 & 88,5 & 1,1 & 3,5 & 88,9 & 2 & 9 & 72,6 \\
\hline 2011 & 1 & 8 & 81,9 & 2,6 & 9 & 41,8 & 0,4 & 9 & 88,6 & 1,1 & 3,5 & 88,10 & 2 & 9 & 70,9 \\
\hline 2012 & 1 & 8 & 81,10 & 2,7 & 9 & 40,9 & 0,4 & 9 & 88,7 & 1,1 & 3,5 & 88,11 & 2 & 9 & 74,6 \\
\hline 2013 & 1 & 8 & 81,11 & 2,8 & 9 & 34,0 & 0,4 & 9 & 88,8 & 1,1 & 3,5 & 88,12 & 2 & 9 & 71,6 \\
\hline 2014 & 1 & 8 & 81,12 & 2,9 & 9 & 34,3 & 0,4 & 9 & 88,9 & 1,1 & 3,5 & 88,13 & 2 & 9 & 72,2 \\
\hline
\end{tabular}

Źródło: opracowanie własne na podstawie: [Doing Business... 2006, 2010, 2015]. 
Upadtość przedsiębiorstw w Polsce...

Tabela 3. Czas (T), koszt (C) oraz stopa zwrotu (Rr) w państwach UE-13 w latach 2005-2014

\begin{tabular}{|c|c|c|c|c|c|c|c|c|c|c|c|c|c|c|c|}
\hline \multirow{2}{*}{ Rok } & \multicolumn{3}{|c|}{ Bułgaria } & \multicolumn{3}{|c|}{ Chorwacja } & \multicolumn{3}{|c|}{ Cypr } & \multicolumn{3}{|c|}{ Czechy } & \multicolumn{3}{|c|}{ Estonia } \\
\hline & $\mathrm{T}$ & $\mathrm{C}$ & $\mathrm{Rr}$ & $\mathrm{T}$ & $\mathrm{C}$ & $\mathrm{Rr}$ & $\mathrm{T}$ & $\mathrm{C}$ & $\mathrm{Rr}$ & $\mathrm{T}$ & $\mathrm{C}$ & $\mathrm{Rr}$ & $\mathrm{T}$ & $\mathrm{C}$ & $\mathrm{Rr}$ \\
\hline 2005 & 3,3 & 9 & 33,5 & 3,1 & 14,5 & 28,5 & - & - & - & 9,2 & 14,5 & 17,8 & 3 & 9 & 39,0 \\
\hline 2006 & 3,3 & 9 & 33,6 & 3,1 & 14,5 & 28,9 & - & - & - & 9,2 & 14,5 & 18,5 & 3 & 9 & 39,9 \\
\hline 2007 & 3,3 & 9 & 33,7 & 3,1 & 14,5 & 30,2 & - & - & - & 6,5 & 14,5 & 21,3 & 3 & 9 & 39,1 \\
\hline 2008 & 3,3 & 9 & 33,8 & 3,1 & 14,5 & 30,5 & 1,5 & 14,5 & 70,7 & 6,5 & 14,5 & 20,9 & 3 & 9 & 37,5 \\
\hline 2009 & 3,3 & 9 & 33,9 & 3,1 & 14,5 & 30,5 & 1,5 & 14,5 & 70,7 & 6,5 & 14,5 & 20,9 & 3 & 9 & 37,5 \\
\hline 2010 & 3,3 & 9 & 33,10 & 3,1 & 14,5 & 28,7 & 1,5 & 14,5 & 70,4 & 3,2 & 17,0 & 55,9 & 3 & 9 & 35,5 \\
\hline 2011 & 3,3 & 9 & 33,11 & 3,1 & 14,5 & 29,8 & 1,5 & 14,5 & 70,8 & 3,2 & 17,0 & 56,0 & 3 & 9 & 36,9 \\
\hline 2012 & 3,3 & 9 & 33,12 & 3,1 & 14,5 & 30,1 & 1,5 & 14,5 & 70,7 & 3,2 & 17,0 & 56,3 & 3 & 9 & 38,5 \\
\hline 2013 & 3,3 & 9 & 33,13 & 3,1 & 14,5 & 30,3 & 1,5 & 14,5 & 70,5 & 2,1 & 17,0 & 65,0 & 3 & 9 & 38,9 \\
\hline 2014 & 3,3 & 9 & 33,14 & 3,1 & 14,5 & 30,5 & 1,5 & 14,5 & 70,5 & 2,1 & 17,0 & 65,6 & 3 & 9 & 39,3 \\
\hline \multirow{2}{*}{ Rok } & \multicolumn{3}{|c|}{ Litwa } & \multicolumn{3}{|c|}{ Łotwa } & \multicolumn{3}{|c|}{ Malta } & \multicolumn{3}{|c|}{ Polska } & \multicolumn{3}{|c|}{ Rumunia } \\
\hline & $\mathrm{T}$ & $\mathrm{C}$ & $\mathrm{Rr}$ & $\mathrm{T}$ & $\mathrm{C}$ & $\mathrm{Rr}$ & $\mathrm{T}$ & $\mathrm{C}$ & $\mathrm{Rr}$ & $\mathrm{T}$ & $\mathrm{C}$ & $\mathrm{Rr}$ & $\mathrm{T}$ & $\mathrm{C}$ & $\mathrm{Rr}$ \\
\hline 2005 & 1,7 & 7,0 & 49,8 & 3,0 & 13,0 & 33,9 & - & - & - & 3 & 15 & 32,1 & 4,6 & 9,0 & 17,5 \\
\hline 2006 & 1,7 & 7,0 & 50,5 & 3,0 & 13,0 & 34,8 & - & - & - & 3 & 15 & 33,8 & 4,6 & 9,0 & 19,9 \\
\hline 2007 & 1,7 & 7,0 & 49,2 & 3,0 & 13,0 & 34,6 & - & - & - & 3 & 15 & 33,7 & 3,3 & 9,0 & 28,9 \\
\hline 2008 & 1,7 & 7,0 & 48,0 & 3,0 & 13,0 & 29,0 & - & - & - & 3 & 15 & 34,1 & 3,3 & 9,0 & 29,5 \\
\hline 2009 & 1,5 & 7,0 & 49,4 & 3,0 & 13,0 & 29,0 & - & - & - & 3 & 15 & 34,1 & 3,3 & 10,5 & 28,5 \\
\hline 2010 & 1,7 & 7,0 & 48,3 & 3,0 & 13,0 & 31,9 & - & - & - & 3 & 15 & 35,8 & 3,3 & 10,5 & 25,7 \\
\hline 2011 & 1,8 & 7,0 & 48,4 & 1,5 & 10,0 & 46,4 & 3,0 & 10 & 39,2 & 3 & 15 & 31,5 & 3,3 & 10,5 & 28,6 \\
\hline 2012 & 1,8 & 7,0 & 48,5 & 1,5 & 10,0 & 47,8 & 3,0 & 10 & 39,2 & 3 & 15 & 54,5 & 3,3 & 10,5 & 29,2 \\
\hline 2013 & 1,9 & 7,0 & 48,4 & 1,5 & 10,0 & 48,4 & 3,0 & 10 & 39,2 & 3 & 15 & 54,8 & 3,3 & 10,5 & 30,0 \\
\hline 2014 & 2,3 & 10,0 & 43,6 & 1,5 & 10,0 & 48,2 & 3,0 & 10 & 39,2 & 3 & 15 & 57,0 & 3,3 & 10,5 & 30,7 \\
\hline \multirow{2}{*}{ Rok } & \multicolumn{3}{|c|}{ Słowacja } & \multicolumn{3}{|c|}{ Słowenia } & \multicolumn{3}{|c|}{ Węgry } & & & & & & \\
\hline & $\mathrm{T}$ & $\mathrm{C}$ & $\mathrm{Rr}$ & $\mathrm{T}$ & $\mathrm{C}$ & $\mathrm{Rr}$ & $\mathrm{T}$ & $\mathrm{C}$ & $\mathrm{Rr}$ & & & & & & \\
\hline 2005 & 4,8 & 18 & 38,6 & 2 & 8,0 & 44,0 & 2 & 14,5 & 35,7 & & & & & & \\
\hline 2006 & 4,0 & 18 & 48,1 & 2 & 8,0 & 44,9 & 2 & 14,5 & 39,7 & & & & & & \\
\hline 2007 & 4,0 & 18 & 45,2 & 2 & 8,0 & 46,6 & 2 & 14,5 & 38,4 & & & & & & \\
\hline 2008 & 4,0 & 18 & 45,9 & 2 & 8,0 & 45,5 & 2 & 14,5 & 38,4 & & & & & & \\
\hline 2009 & 4,0 & 18 & 45,9 & 2 & 8,0 & 45,5 & 2 & 14,5 & 38,4 & & & & & & \\
\hline 2010 & 4,0 & 18 & 55,3 & 2 & 4,0 & 50,9 & 2 & 14,5 & 37,9 & & & & & & \\
\hline 2011 & 4,0 & 18 & 54,3 & 2 & 4,0 & 51,1 & 2 & 14,5 & 39,2 & & & & & & \\
\hline 2012 & 4,0 & 18 & 53,6 & 2 & 4,0 & 49,8 & 2 & 14,5 & 38,8 & & & & & & \\
\hline 2013 & 4,0 & 18 & 54,1 & 2 & 4,0 & 50,1 & 2 & 14,5 & 38,3 & & & & & & \\
\hline 2014 & 4,0 & 18 & 54,4 & 2 & 4,0 & 50,1 & 2 & 14,5 & 40,2 & & & & & & \\
\hline
\end{tabular}

Źródło: opracowanie własne na podstawie: [Doing Business... 2006, 2010, 2015]. 
przeprowadzenia upadłości jest w Irlandii ( $0,4 \mathrm{w}$ całym badanym okresie) oraz Belgii $(0,9)$.

Znacznie większe zróżnicowanie zauważa się w koszcie procesu upadłościowego. Najniższy jest w Belgii, Holandii $(3,5 \%)$ oraz Danii $(4 \%)$, a najwyższy we Włoszech (22\%), Luksemburgu (14,5\%) oraz Hiszpanii (11\%). W badanej grupie krajów koszt upadłości w latach 2005-2014 w zasadzie nie ulegał zmianie i w każdym roku uzyskiwał tę samą wartość. Wyjątkiem są Austria i Hiszpania, w których w badanym okresie obniżył się odpowiednio z 18 do $10 \%$ dla Austrii oraz z 14,5 do $11 \%$ w przypadku Hiszpanii.

Krajami o najwyższej stopie zwrotu są Finlandia $(88,9)$, Irlandia $(88,9)$, Wielka Brytania $(88,6)$ i Holandia $(88,12)$. W państwach tych zarówno czas i koszt procesu upadłościowego są niskie. Krajami o najniższej stopie zwrotu są Grecja, Luksemburg i Francja [Doing Business... 2006, 2010, 2015]. Opisane powyżej wskaźniki przedstawia rys. 1 .

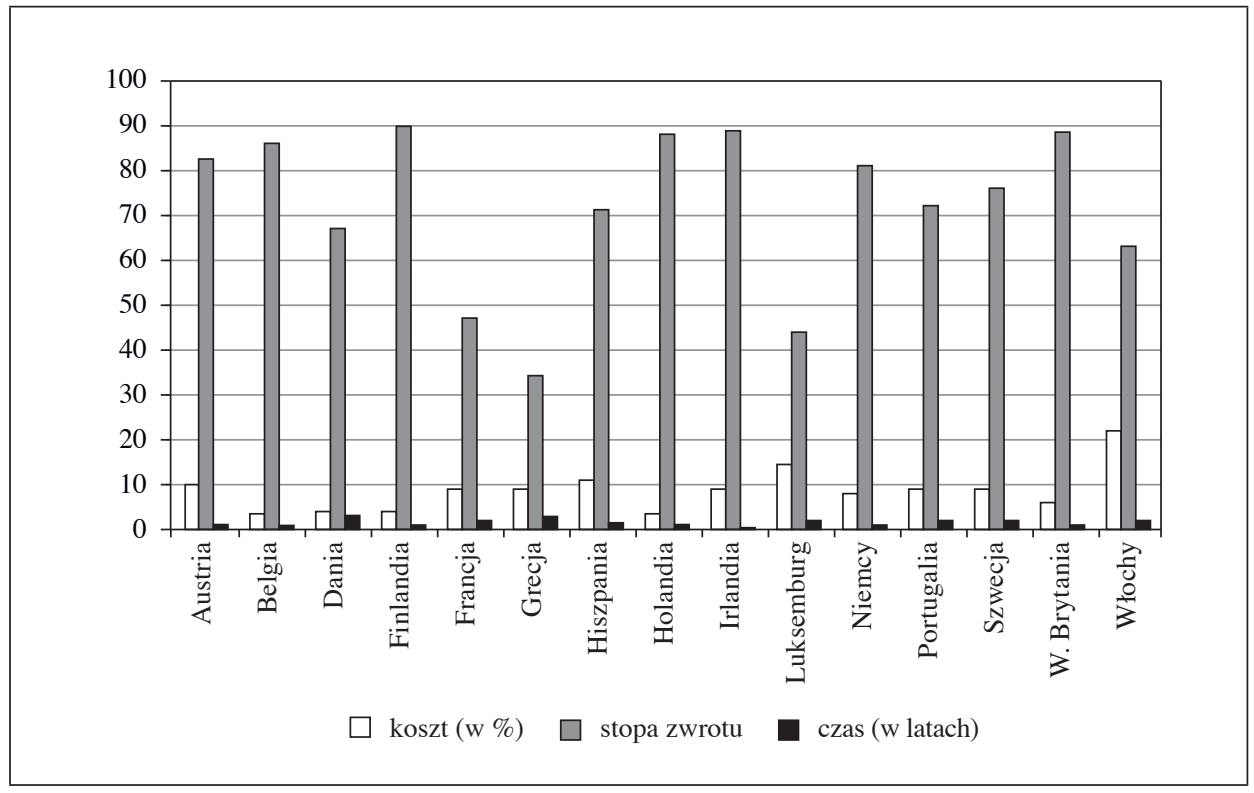

Rys. 1. Koszt postępowania upadłościowego, czas oraz stopa zwrotu w krajach UE-15 w $2014 \mathrm{r}$.

Źródło: opracowanie własne na podstawie: [Doing Business... 2015].

Dokonując analogicznej analizy czasu, kosztu oraz stopy zwrotu drugiej badanej grupy krajów (UE-13), w skład której wchodzi Polska oraz państwa, które 
z nią przystąpiły do UE, a także Bułgaria, Chorwacja i Rumunia, zaobserwować można następujące prawidłowości:

- wyższy czas postępowania upadłościowego niż w krajach zachodnich (trzy lub więcej lat w przypadku większości badanych krajów, z wyjątkiem Cypru i Łotwy $(1,5)$, Węgier (2), Czech $(2,1)$ i Litwy $(2,3)$;

- wyższy koszt upadłości sięgający nawet 18\% w przypadku Słowacji, 17\% w Czechach oraz 15\% w Polsce;

- zdecydowanie niższa stopa zwrotu: Chorwacja $(30,5)$, Rumunia $(30,7)$, Bułgaria $(33,1)$. Wskaźnik dla Polski wynosi 57. Krajami o najwyższej stopie zwrotu są Cypr $(70,5)$ i Czechy $(65,6)$ [Doing Business... 2015].

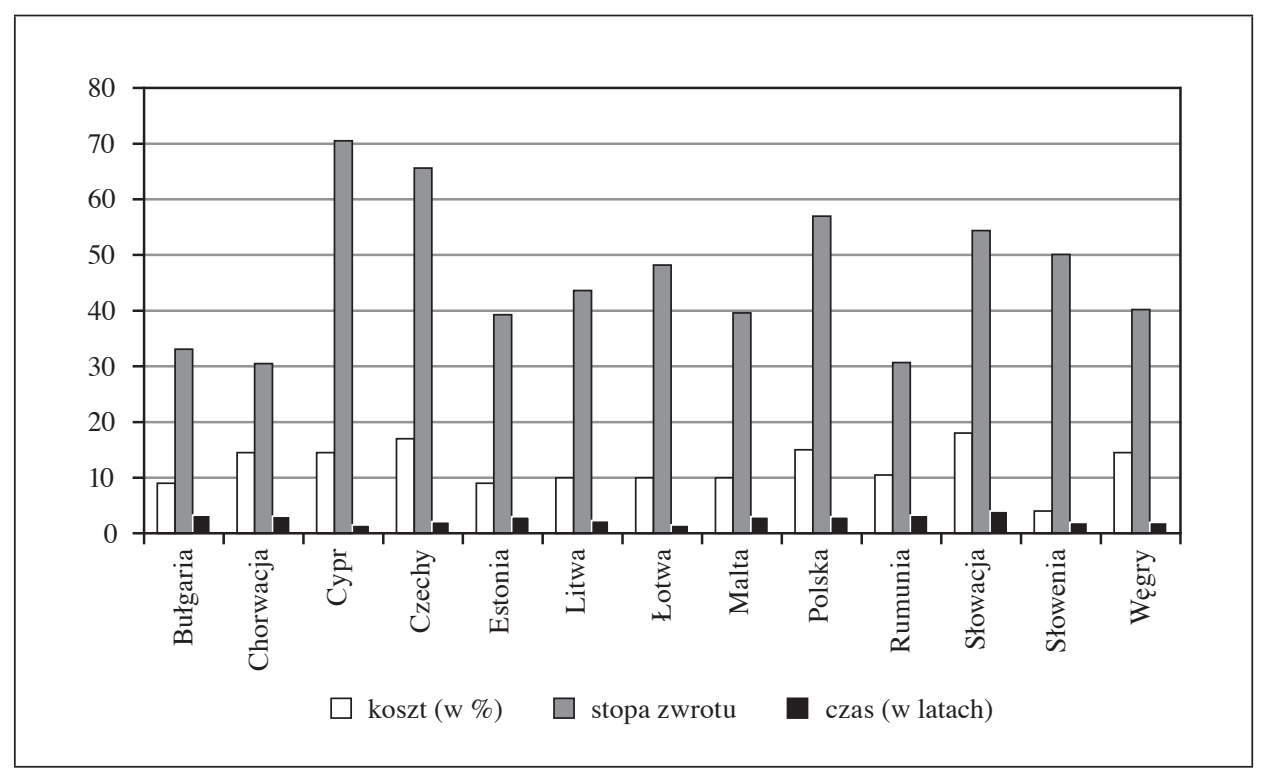

Rys. 2. Koszt postępowania upadłościowego, czas oraz stopa zwrotu w krajach UE-13 w $2014 \mathrm{r}$.

Źródło: opracowanie własne na podstawie: [Doing Business... 2015].

Porównanie czasu, kosztu oraz stopy zwrotu pomiędzy dwoma grupami krajów (UE-15 oraz UE-13) wykazało duże rozbieżności w prezentowanych wartościach. Nowe kraje UE osiągają gorsze wyniki dla badanych wskaźników, stąd można wysunąć wniosek, że implementacja unijnego prawa upadłościowego i międzynarodowych dobrych praktyk upadłościowych znacząco wpływa na ulepszenie procedur krajowych, a tym samym upraszcza proces likwidacji przedsiębiorstwa. Sprawny i przyjazny system zachęca przedsiębiorców do wybrania sformalizowanej formy likwidacji działalności. 
Dla lepszego zobrazowania różnic pomiędzy badanymi grupami krajów w tabeli 4 ujęto średnie wartości omawianych wskaźników oraz wartości dla Polski.

Tabela 4. Średni czas, koszt oraz stopa zwrotu w 2014 r.

\begin{tabular}{|l|c|c|c|}
\hline \multicolumn{1}{|c|}{ Wskaźniki } & UE-15 & UE-13 & Polska \\
\hline Średni czas (lata) & 1,6 & 2,62 & 3 \\
\hline Średni koszt (\%) & 8,77 & 12 & 15 \\
\hline Średnia stopa zwrotu & 72,05 & 46,37 & 57 \\
\hline
\end{tabular}

Źródło: opracowanie własne na podstawie: [Doing Business... 2015].

Z tabeli 4 wynika, że w Polsce przeprowadzenie procesu upadłościowego jest długie i kosztowne. Stopa zwrotu niewiele wyższa od średniej nowo przyjętych państw unijnych i jednocześnie daleka od średniej państw UE-15 zniechęcać może do sformalizowanej formy opuszczenia rynku.

Tabela 5. Procedura likwidacji przedsiębiorstwa w Polsce w latach 2004-2014

\begin{tabular}{|l|c|c|c|c|c|c|c|c|c|c|c|}
\hline Wyszczególnienie & 2014 & 2013 & 2012 & 2011 & 2010 & 2009 & 2008 & 2007 & 2006 & 2005 & 2004 \\
\hline $\begin{array}{l}\text { Miejsce w ran- } \\
\text { kingu DB }\end{array}$ & 32 & 37 & 37 & 87 & 77 & 85 & 82 & 88 & 85 & - & - \\
\hline $\begin{array}{l}\text { Okres likwidacji } \\
\text { firmy (w latach) }\end{array}$ & 3 & 3 & 3 & 3 & 3 & 3 & 3 & 3 & 3 & 3 & 3 \\
\hline $\begin{array}{l}\text { Koszt likwidacji } \\
\text { firmy (w \% warto- } \\
\text { ści nieruchomości } \\
\text { firmy) }\end{array}$ & 15 & 15 & 15 & 15 & 15 & 15 & 15 & 15 & 15 & 15 & 15 \\
\hline Stopa zwrotu & 57,0 & 54,8 & 54,8 & 31,5 & 35,8 & 34,1 & 34,1 & 33,7 & 33,8 & 32,1 & 32,4 \\
\hline
\end{tabular}

Źródło: opracowanie własne na podstawie raportów: [Doing Business... 2005-2015].

$\mathrm{Z}$ danych zaprezentowanych w tabeli 5 wynika, że w okresie 10 lat Polska zmieniła miejsce w rankingu Doing Business. Wpływ na tę sytuację miały zmiany w polskim prawie upadłościowym. Ostatnia z nich miała miejsce w czerwcu 2015 r., kiedy to Prezydent RP podpisał ustawę nowelizującą dotychczasowe prawo restrukturyzacyjne, której celem jest ochrona wartości ekonomicznej firmy i zapewnienie firmom znajdującym się w trudnej sytuacji gospodarczej szansy na kontynuowanie działalności poprzez dostęp przedsiębiorców do narzędzi prawnych umożliwiających przeprowadzanie efektywnej restrukturyzacji przedsiębiorstwa. Upadłość i likwidacja, pojmowana jako ostateczność, ma być szybka i tania. Zmiany objąć mają przede wszystkim rozdzielenie procedur restrukturyzacyjnych 
i naprawczych od postępowania upadłościowego, wprowadzenie czterech rodzajów postępowań restrukturyzacyjnych, zmianę definicji niewypłacalności dłużnika, tak aby decydujące znaczenie miała faktyczna niewypłacalność. Projekt wpisuje się w przyjętą 22 lipca 2014 r. przez Radę Ministrów Politykę Nowej Szansy, która udostępnia wiele instrumentów na rzecz ograniczania ryzyka likwidacji i sprawnego przeprowadzenia upadłości przedsiębiorstw (www.mg.gov.pl, dostęp: 14.07.2015).

Działania realizowane w ramach Polityki Nowej Szansy koncentrują się na następujących obszarach: zapobieganiu sytuacjom kryzysowym przedsiębiorstw (systemy wczesnego ostrzegania), ograniczaniu ryzyka likwidacji przedsiębiorstw (pozasądowe formy naprawy i restrukturyzacji), sprawnym przeprowadzeniu likwidacji przedsiębiorstw (sądowe formy restrukturyzacji i likwidacji), nowej szansie (oddłużenie, działania po ogłoszeniu upadłości przedsiębiorstwa, ponowne podjęcie działalności gospodarczej), działaniach promocyjnych (kampania informacyjno-promocyjna na rzecz promocji dobrego zarządzania oraz racjonalnego podejścia do zagadnienia porażki biznesowej) [Polityka nowej szansy 2014].

Dotychczasowa ocena procesu upadłościowego, opierająca się na określeniu trzech wskaźników (czasu, kosztu oraz stopy zwrotu), opierała się na ocenach praktyków upadłościowych poszczególnych państw członkowskich. W najnowszych badaniach metodologią badań nad procesem upadłościowym objęto dłużników i niezabezpieczonych wierzycieli, podczas gdy wcześniej koncentrowano się głównie na zabezpieczonych wierzycielach. Istotne zmiany w badaniach nad procesem upadłościowym dotyczą pełniejszych oraz zrównoważonych ocen nie tylko przepisów prawa poszczególnych państw członkowskich, ale również implementacji dobrych praktyk rekomendowanych przez Bank Światowy w zakresie upadłości.

Wskaźnik siły upadłości mierzy czy i w jakim stopniu gospodarki narodowe wcieliły międzynarodowe, powszechne standardy procesu upadłościowego i dotyczy takich czterech obszarów, jak:

- proces upadłościowy - jaki rodzaj postępowania (likwidacja, reorganizacja, czy połączenie obu) dłużnicy i wierzyciele mogą rozpocząć i jakie jest typowe postępowanie w celu ogłoszenia upadłości dłużnika,

- zarządzanie majątkiem dłużnika - czy podczas procesu upadłościowego dłużnik może prowadzić działania niezbędne do dalszego funkcjonowania przedsiębiorstwa, a zakończyć kontrakty nieefektywne, oraz czy może w trakcie procesu upadłościowego pozyskać dodatkowe finansowanie w celu podtrzymania bieżącej działalności firmy,

- postępowanie naprawcze - czy i w jaki sposób, wierzyciele głosują nad planem restrukturyzacji oraz jakie są dostępne środki ochrony dla pozostałych wierzycieli, 
- udział wierzycieli w postępowaniu upadłościowym - czy wierzyciele mają wpływ na podejmowanie kluczowych decyzji, takich jak mianowanie przedstawiciela upadłościowego lub sprzedaż majątku, czy wierzyciele mają dostęp do informacji dotyczących dłużnika i samego procesu oraz czy mogą zgłosić sprzeciw wobec ich praw, takich jak zatwierdzone wnioski złożone przez innych wierzycieli [Doing Business... 2015].

W tabeli 6 przedstawiono wyniki badań, co pomogło określić wskaźnik siły upadłości dla poszczególnych państw w 2014 r. Wskaźnik siły upadłości, której wartość jest sumą części składowych staje się pomocnym narzędziem głównie dla ustawodawców do ulepszania prawa upadłościowego, ponieważ ukazuje on obszary, w których są pewne braki. Jego wartość wahać się może w przedziale 0-16. Im wartość wyższa tym procedury upadłościowe danego kraju bardziej rozwinięte, zgodne z dobrymi międzynarodowymi praktykami upadłościowymi. Wysoki wskaźnik siły upadłości oznacza również, że badany kraj zakończył proces adaptacji prawa upadłościowego, bądź trwa on na tyle długo, by wpłynąć realnie na poprawę przeprowadzenia upadłości przedsiębiorstwa. Z danych opracowanych przez Bank Światowy w raporcie Doing Business... 2015 nasuwa się wniosek, że procedury upadłościowe państw członkowskich Unii (poza Cyprem, Maltą i Litwą) oceniane są dobrze lub bardzo dobrze. Trudno nawet stwierdzić, że państwa „nowej Unii” wyraźnie różnią się od pozostałych członków Wspólnoty w kwestii prawnych regulacji upadłościowych.

Pytanie, jakie nasuwa się po dotychczasowej analizie wskaźników upadłościowych w UE, dotyczy rozbieżności między czasem, kosztem i stopą zwrotu a oceną prawnych uregulowań państw członkowskich. Zastanawiający jest przypadek chociażby Irlandii, której ocena prawnych uregulowań w kwestii niewypłacalności przedsiębiorstw wypadła słabo, osiągając wartość 9 w 16-punktowej skali, charakteryzuje się jednocześnie bardzo wysoką stopą zwrotu $(88,9)$, niskim okresem likwidacji $(0,4)$ i niskim jej kosztem $(9)$. Warto odnotować przypadek Bułgarii, która w 2014 r. miała niską stopę zwrotu $(33,1)$ i długi czas $(3,3)$, przy czym w ocenie uregulowań prawnych mierzonych wskaźnikiem siły upadłości osiągnęła aż 15 punktów. Wskaźnik siły upadłości regulacji formalnoprawnych nie odzwierciedla zatem rzeczywistości ujętej we wskaźnikach czasu, kosztu i stopy zwrotu. W tabeli 6 znajduje się ponadto ocena rozwiązań w obszarze niewypłacalności wyrażona w formie pozycji rankingowej poszczególnych państw UE opracowana przez Bank Światowy. O niewystarczających rozwiązaniach prawnych w zakresie niewypłacalności i mało skutecznych systemach upadłościowych świadczy miejsce większości państw „nowej Unii”, w tym Polski - 32. w 2014 r. Wśród państw nowo przyjętych tylko system prawny Czech i Słowacji oceniony został wyżej od systemu Polski. 
Tabela 6. Wskaźnik siły upadłości w 2014 r. oraz jego elementy składowe dla państw UE

\begin{tabular}{|c|c|c|c|c|c|c|}
\hline $\begin{array}{l}\text { Kraje człon- } \\
\text { kowskie Unii } \\
\text { Europejskiej }\end{array}$ & $\begin{array}{l}\text { Regulacje } \\
\text { prawne - } \\
\text { ranking }\end{array}$ & \begin{tabular}{|c|} 
Rozpoczęcie \\
procesu upa- \\
dłościowego \\
$(0-3)$
\end{tabular} & $\begin{array}{c}\text { Zarządzanie } \\
\text { majątkiem } \\
\text { dłużnika } \\
(0-6)\end{array}$ & $\begin{array}{l}\text { Postępo- } \\
\text { wanie } \\
\text { naprawcze } \\
(0-3)\end{array}$ & $\begin{array}{c}\text { Udział } \\
\text { wierzyciela } \\
\text { w postępo- } \\
\text { waniu }(0-4)\end{array}$ & $\begin{array}{l}\text { Wskaźnik } \\
\text { siły } \\
\text { upadłości } \\
(0-16)\end{array}$ \\
\hline Austria & 16 & 2,5 & 5,5 & 1,0 & 2,0 & 11,0 \\
\hline Belgia & 11 & 2,5 & 6,0 & 1,0 & 2,0 & 11,5 \\
\hline Bułgaria & 38 & 2,5 & 6,0 & 2,5 & 4,0 & 15,0 \\
\hline Chorwacja & 56 & 3,0 & 4,0 & 3,0 & 2,0 & 12,0 \\
\hline Cypr & 51 & 2,0 & 2,0 & 0,0 & 2,0 & 6,0 \\
\hline Czechy & 20 & 3,0 & 5,5 & 3,0 & 2,0 & 13,5 \\
\hline Dania & 9 & 3,0 & 6,0 & 1,0 & 2,0 & 12,0 \\
\hline Estonia & 37 & 2,5 & 5,5 & 2,0 & 4,0 & 14,0 \\
\hline Finlandia & 1 & 3,0 & 6,0 & 2,5 & 3,0 & 14,5 \\
\hline Francja & 22 & 3,0 & 6,0 & 1,0 & 1,0 & 11,0 \\
\hline Grecja & 52 & 2,5 & 5,5 & 3,0 & 1,0 & 12,0 \\
\hline Hiszpania & 23 & 3,0 & 6,0 & 2,0 & 1,0 & 12,0 \\
\hline Holandia & 12 & 2,5 & 6,0 & 1,0 & 2,0 & 11,5 \\
\hline Irlandia & 21 & 3,0 & 3,5 & 2,0 & 1,0 & 9,5 \\
\hline Litwa & 67 & 2,5 & 4,0 & 0,5 & 1,0 & 8,0 \\
\hline Luksemburg & 62 & 2,5 & 5,0 & 0,5 & 1,0 & 9,0 \\
\hline Łotwa & 40 & 2,5 & 5,0 & 2,5 & 2,0 & 12,0 \\
\hline Malta & 86 & 2,5 & 2,0 & 0,0 & 3,0 & 7,5 \\
\hline Niemcy & 3 & 3,0 & 6,0 & 3,0 & 3,0 & 15,0 \\
\hline Polska & 32 & 3,0 & 6,0 & 2,5 & 1,0 & 12,5 \\
\hline Portugalia & 10 & 3,0 & 5,5 & 3,0 & 3,0 & 14,5 \\
\hline Rumunia & 46 & 3,0 & 6,0 & 2,5 & 2,0 & 13,5 \\
\hline Słowacja & 31 & 3,0 & 4,0 & 3,0 & 3,0 & 13,0 \\
\hline Słowenia & 42 & 2,5 & 6,0 & 2,0 & 1,0 & 11,5 \\
\hline Szwecja & 17 & 3,0 & 6,0 & 1,0 & 2,0 & 12,0 \\
\hline W. Brytania & 13 & 3,0 & 5,0 & 1,0 & 2,0 & 11,0 \\
\hline Węgry & 64 & 2,5 & 5,0 & 0,5 & 1,0 & 9,0 \\
\hline Włochy & 29 & 2,5 & 5,5 & 2,0 & 2,0 & 12,0 \\
\hline
\end{tabular}

Źródło: http://www.doingbusiness.org/data/exploretopics/resolving-insolvency (dostęp: 25.10.2015).

Rozbieżności w systemach prawnych państw członkowskich (jedne sprzyjające dłużnikowi, inne wierzycielowi, bądź jedne nastawione na reorganizację, a drugie na likwidację) powinny wymuszać harmonizację unijnego prawa upadłościowego. 
Z dotychczasowych badań wynika, że postępowania upadłościowe są najbardziej efektywne w tych krajach, w których są wszczynane, oraz których aktywów dotyczą. Harmonizacja ograniczy występowanie forum shopping, zjawiska polegającego na celowej zmianie, przeniesieniu centrum interesów dłużnika na jurysdykcję bardziej dla niego korzystną. Zbliżanie krajowych ustawodawstw do poziomu wspólnotowego zwiększy przejrzystość procedur upadłościowych, a w konsekwencji ich efektywność [Kupis i Zaniewska 2013].

\section{Podsumowanie}

Analiza procesu upadłościowego poszczególnych państw członkowskich pozwoliła stwierdzić, że Polska jest krajem o mało skutecznym systemie upadłościowym. Wskazuje na to przede wszystkim niska stopa zwrotu w postępowaniu upadłościowym, przy jednoczesnych wysokich jego kosztach i długim okresie likwidacji przedsiębiorstwa. Wartości dla Polski znacząco różnią się od średnich wartości wskaźników dla państw UE-15, a nawet średni czas i koszt postępowania jest wyższy niż średnia dla krajów razem przystępujących z Polską do Wspólnoty Europejskiej. Analiza wskaźnika siły upadłości wykazała, że Polska charakteryzuje się bardzo niskim udziałem wierzycieli w postępowaniu upadłościowym. Ta nieefektywność systemu nie zachęca przedsiębiorców do podejmowania prawnych kroków w celu zaprzestania prowadzenia działalności. Pomimo to ocena procedury upadłościowej w Polsce, wyrażona w pozycji rankingowej opracowanej w corocznych raportach Doing Business w okresie 10 lat znacznie się poprawiła, z 85 miejsca w 2005 r. Polska w 2014 r. znalazła się na 32 miejscu. Skuteczność systemów upadłościowych wybranych państw Unii oceniona została w raporcie Komisji Europejskiej w 2011 r. W trzystopniowej skali skuteczności (wysoka, średnia, niska) Polska znalazła się w grupie krajów o średniej skuteczności systemów upadłościowych, jednak daleko za państwami skandynawskimi czy Wielką Brytanią, w których skuteczność oceniono najwyżej. Polska uplasowała się za takimi krajami, jak Bułgaria, Rumunia czy Grecja, pomimo że są to państwa o niższej stopie zwrotu niż Polska. Jako najmniej skuteczne systemy upadłościowe w raporcie Komisji Europejskiej oceniono systemy Chorwacji, Czech i Litwy [Business Dynamics: Start-ups... 2011].

Podsumowując, regulacje prawne systemów upadłościowych, ich przejrzystość a także skuteczność, są ważnym czynnikiem decydującym czy przedsiębiorstwo wybierze formalną, czy nieformalną formę wyjścia z rynku. 


\section{Literatura}

Armatowska M. [2011], Uznanie zagranicznych postępowań upadłościowych na podstawie Rozporzadzenia Rady (WE) NR 1346/2000 w sprawie postęowania upadtościowego, Lex Wolters Kluwer business, Warszawa.

Business Dynamics: Start-ups, Business Transfers and Bankruptcy [2011], European Commission, http://docplayer.net/12092095-Business-dynamics-start-ups-businesstransfers-and-bankruptcy.html (dostęp: 14.07.2015).

Doing Business 2010. Reforming through Difficult Times [2010], The World Bank, http:// www.doingbusiness .org/ /media/GIAWB/Doing\%20Business/Documents/AnnualReports/English/DB10-FullReport.pdf (dostęp: 14.07.2015).

Doing Business 2015. Going Beyond Efficiency [2015], The World Bank, http://www. doingbusiness.org/ /media/GIAWB/Doing\%20Business/Documents/Annual-Reports/ English/DB15-Full-Report.pdf (dostęp: 14.07.2015).

Doing Business in 2006. Creating Jobs [2006], The World Bank, http://www.doingbusiness.org/ /media/GIAWB/Doing\%20Business/Documents/Annual-Reports/English/ DB06-FullReport.pdf (dostęp: 14.07.2015).

Insolvenzen in Europa [2005-2015], raporty Creditreform, http://www.creditreform.de/ aktuelles/wirtschaftsforschung/insolvenzen-in-europa.html (dostęp: 14.07.2015).

Kupis P., Zaniewska K. [2013], Zbliżenia ustawodawstwa - dotychczasowe efekty i wyzwania [w:] Procesy upadłościowe i naprawcze w Polsce na tle doświadczeń Unii Europejskiej, red. E. Mączyńska, Oficyna Wydawnicza SGH, Warszawa.

Polityka nowej szansy [2014], Ministerstwo Gospodarki, http://www.mg.gov.pl/files/ upload/21202/Polityka\%20Nowej\%20Szansy_przyjeta_przez_RM_22072014.pdf (dostęp: 14.07.2015).

Prusak B. [2011], Ekonomiczna analiza upadłości przedsiębiorstw: ujęcie międzynarodowe, Wydawnictwa Fachowe CeDeWu.pl, Warszawa.

Zedler F., Hrycaj A., Filipiak P. [2011], Europejskie prawo upadłościowe, Komentarz, Lex Wolters Kluwer business, Warszawa.

\section{Company Bankruptcy in Poland and Other European Union Countries in the Period 2005-2014}

(Abstract)

Bankruptcy is an inherent element of any market economy and can affect any company. The number of bankruptcies in Poland in comparison to other EU countries in the period 2005-2014 is analysed. Additionally, this study evaluates the bankruptcy process among Member States on the basis of such assessment indicators including: time required to liquidate the company, the cost and recovery rate. The research hypothesis assumes that the course of the bankruptcy process depends on the quality of insolvency law. Analysis of the data revealed that in Poland the course of the bankruptcy process is long and expensive, while the recovery rate is low. Poland's inefficient bankruptcy process discourages enterprises from choosing the path of formal exit from the market and places Poland far down the ranking of insolvency systems in Europe.

Keywords: insolvency proceedings, bankruptcy, insolvency law, insolvency system. 